\title{
Nonmydriatic retinal photography in the evaluation of acute neurologic conditions
}

Khichar Shubhakaran, MBBS, MD: The article by Bidot et al. ${ }^{1}$ is worth appreciation. I would like to share my additional views on this important clinical device. Ophthalmoscopy is an important bedside test by which a clinician can diagnose, offer a differential diagnosis in an undiagnosed patient, and — once diagnosed — contribute to prognosis in various infectious and noninfectious diseases. These tests are well-described in certain noncommunicable diseases, but need validation by randomized double-blind trials in infectious diseases such as malaria and dengue. $^{2-4}$ When a patient in critical condition presents to the emergency department, ophthalmoscopy without pupillary dilatation (time sparing) may be a useful clinical tool for diagnosis. Furthermore, pupillary dilation may at times bias the follow-up examination of such a patient as pupillary light reflex is an important tool for a patient's critical status examination. Nonmydriatic ocular fundus photography may represent a promising tool to direct ophthalmoscopy in an emergency department. Underappreciation of the importance of ocular fundus examination can place patients at risk for poor outcome and expose caregivers to medico-legal liability. Photography prevents interobserver variability and can be sent to a distant colleague for consultation. Electronic recordkeeping of such findings can populate a large database for future reference.

Dr. S.N. Medical College, Jodhpur, India.

Disclosures: The author reports no disclosures.

Authors Respond: Samuel Bidot, MD, Beau B. Bruce, MD, Nancy J. Newman, MD, Valérie Biousse, MD: The authors thank Dr. Shubhakaran for his comments on our article ${ }^{1}$ and for sharing his views about the importance of fundus examination. We agree that nonophthalmologist physicians doing general and neurologic examinations perform ophthalmoscopy infrequently, and often poorly, even when clearly indicated. ${ }^{5}$ Dr. Subhakaran touches on many important advantages of nonmydriatic fundus camera over direct ophthalmoscopy, including better diagnostic accuracy, lower risk of medico-legal liability, objective recording for future comparison, and possibility of telemedicine. We showed that nonmydriatic fundus photographs have a role in the acute evaluation of neurologic conditions, ${ }^{1}$ but their use may be extended to many other medical settings, such pediatric ophthalmology ${ }^{6}$ or even infectious diseases in endemic areas as described by Dr. Subhakaran. Nonmydriatic fundus photographs have numerous assets and may become the gold standard for funduscopic evaluation for tomorrow's nonophthalmologist care providers.

Emory Eye Center, The Emory Clinic, Atlanta, GA.

Disclosures: S. Bidot receives research support from Berthe Fouassier's Foundation (Paris, France) and Philippe Foundation (New York, NY). B. Bruce serves as a consultant for Kaiser Permanente of Georgia for the CDC Vaccine Safety Datalink; receives research support from Teva Pharmaceuticals, Pfizer, Novartis, and the NIH; and was a recipient of the Practice Research Fellowship. N. Newman serves as an associate editor for the Journal of NeuroOphthalmology, on the editorial board of the Journal of the Neurological Sciences, and as executive editor of the American Journal of Ophthalmology; receives publishing royalties for Neuro-Ophthalmology Illustrated (Thieme, 2009), Walsh \& Hoyt's Clinical Neuro-Ophthalmology The Essentials, 1st and 2nd editions (Lippincott Williams \& Wilkins, 1999, 2008), Walsh \& Hoyt's Clinical Neuro-Ophthalmology, 5th and 6th editions (Lippincott Williams \& Wilkins, 1998, 2005), and Blue Books of Neurology: Neuro-Ophthalmology (Butterworth Heinemann Elsevier, 2008); serves as a consultant for Santhera Pharma, Trius Pharma, and Anabasis; received the Research to Prevent Blindness Lew R. Wasserman Merit Award; and has provided expert testimony on the topic of papilledema. V. Biousse serves on the editorial boards of the American Journal of Ophthalmology and the Journal of Neuro-ophthalmology; receives publishing royalties for Walsh and 
Hoyt's Clinical Neuro-Ophthalmology (Williams \& Wilkins) and Neuro-Ophthalmology Illustrated (Thieme); and receives research support from Anabasis and Research to Prevent Blindness.

1. Bidot S, Bruce BB, Newman NJ, Biousse V. Nonmydriatic retinal photography in the evaluation of acute neurologic conditions. Neurol Clin Pract 2013;3:527-531.

2. Shubhakaran K, Khichar RJ. Nonmydriatic ocular fundus photography among headache patients in an emergency department. Neurology 2013;81:1366-1367.

3. Shubhakaran, Jakhar R. Ocular changes in infectious diseases. JAPI 2005;53:913-914.

4. Kochar DK, Shubhakaran, Kumawat BL, et al. Ophthalmoscopic abnormalities in adults with falciparum malaria. Q J Med 1998;91:845-852.

5. Bruce BB, Lamirel C, Wright DW, et al. Nonmydriatic ocular fundus photography in the emergency department. N Engl J Med 2011;364:387-389.

6. Toffoli D, Bruce BB, Lamirel C, Henderson AD, Newman NJ, Biousse V. Feasibility and quality of nonmydriatic fundus photography in children. J AAPOS 2011;15:567-572.

\section{The practice of neuroimaging within a neurology office setting}

Vernon Rowe, MD: The article by Dr. Fritz ${ }^{1}$ describes how large groups of neurologists can incorporate MRI neuroimaging into their practice. In addition, for smaller groups of neurologists, alternative choices exist that can markedly reduce equipment cost and result in a break-even point for as little as 15 scans per week. The availability of lower-cost scanners to small groups, with high-quality interpretation available on-site or digitally outsourced to qualified physicians, allows better patient access, reduced cost of scanning, and improved continuity of care, especially for patients residing in rural areas and urban clusters (nearly $30 \%$ of the US population).

In-office imaging is critical for streamlined integrated outpatient care, and markedly reduces the cost of care. The In Office Ancillary Services Exception to the Stark Law (IOASE) is critical to insuring patient access to appropriate medical care. It is supported by 23 professional organizations representing over 300,000 physicians, not only neurologists but also orthopedists, neurosurgeons, urologists, and more, who signed a letter to Congress supporting the IOASE. All physicians should communicate with their congressional representatives concerning the critical importance of retaining the IOASE for the preservation of streamlined lower cost integrated care in the outpatient setting.

Rowe Neurology Institute, Lenexa, KS.

Disclosures: The author reports no disclosures.

Author Responds: Joseph V. Fritz, PhD: I thank Dr. Rowe for pointing out alternative imaging equipment options appropriate for lower-volume practices. The intent of the pro forma in the original article is to demonstrate the business analysis process using just 2 of many possible examples. The reader is encouraged to work closely with equipment vendors, local payers, and consultants to determine actual expenses, payment models, and imaging center requirements. As we move into an era of value-based payments based on episode-of-care cost and quality, it is indeed critical that specialists retain the rights to operate cost-effective comprehensive practice models.

Dent Neurologic Institute, Amherst, NY.

Disclosures: J. Fritz is a full-time employee of the Dent Neurologic Institute, a private neurology group practice that self-refers imaging, is a Board of Directors member of the American Society of Neuroimaging, and has received travel and speaker honoraria from the American Academy of Neurology.

1. Fritz JV. The practice of neuroimaging within a neurology office setting. Neurol Clin Pract 2013;3: 501-509. 


\title{
Neurology ${ }^{\circ}$ Clinical Practice
}

\author{
The practice of neuroimaging within a neurology office setting \\ Vernon Rowe and Joseph V. Fritz \\ Neurol Clin Pract 2014;4;95 \\ DOI 10.1212/01.CPJ.0000446467.13805.3e
}

This information is current as of April 14, 2014

$\begin{array}{ll}\begin{array}{l}\text { Updated Information \& } \\ \text { Services }\end{array} & \begin{array}{l}\text { including high resolution figures, can be found at: } \\ \text { http://cp.neurology.org/content/4/2/95.full.html }\end{array} \\ \text { References } & \begin{array}{l}\text { This article cites } 1 \text { articles, } 1 \text { of which you can access for free at: } \\ \text { http://cp.neurology.org/content/4/2/95.full.html\#\#ref-list-1 }\end{array} \\ \text { Permissions \& Licensing } & \begin{array}{l}\text { Information about reproducing this article in parts (figures,tables) or in } \\ \text { its entirety can be found online at: } \\ \text { http://cp.neurology.org/misc/about.xhtml\#permissions }\end{array} \\ \text { Reprints } & \begin{array}{l}\text { Information about ordering reprints can be found online: } \\ \text { http://cp.neurology.org/misc/addir.xhtml\#reprintsus }\end{array}\end{array}$

Neurol Clin Pract is an official journal of the American Academy of Neurology. Published continuously since 2011, it is now a bimonthly with 6 issues per year. Copyright (C) 2014 American Academy of Neurology. All rights reserved. Print ISSN: 2163-0402. Online ISSN: 2163-0933.

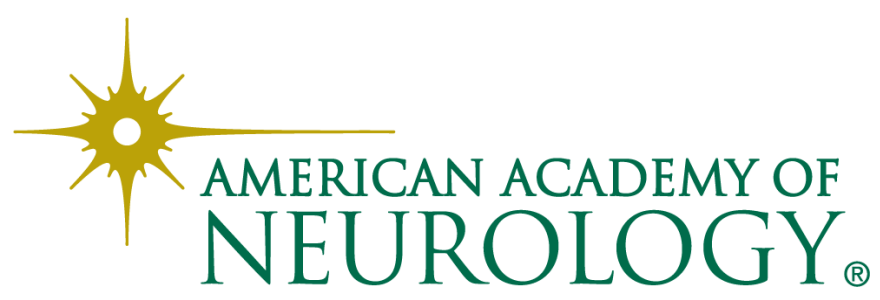

